\title{
The role of RAGE and its ligands, AGEs, in hypertension and cardiovascular diseases
}

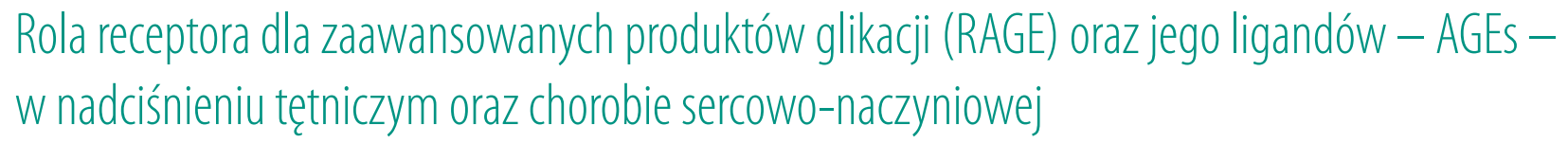

\section{Department of Paediatrics and Nephrology, Medical University of Bialystok, Białystok, Poland}

Correspondence: Marta Lemiesz, MD, Department of Paediatrics and Nephrology, Medical University of Bialystok, Waszyngtona 17, 15-274 Białystok, Poland, tel.: +48 857450828 , fax: +48 85 742 1838, e-mail:me.pszzzolkowska@gmail.com

\begin{abstract}
Dietary advanced glycation end products (AGEs) and their interactions with soluble receptors for advanced glycation end products (sRAGE) play an essential role in the pathogenesis of numerous diseases. RAGE belongs to the immunoglobulin superfamily of receptors that bind several classes of ligands, such as S100/calgranulin family, amyloid $\beta$ peptides, leukocyte b2 integrin, transthyretin and AGEs. Their production and release cause further interaction with their cell-bound receptor (RAGE), resulting in generation of oxygen radicals, nuclear factor kappa- $\beta$, proinflammatory cytokines and cell adhesion molecules. The soluble isoform of receptors for advanced glycation end products acts against the adverse effects of AGE-RAGE interaction by competing with RAGE for binding with AGE. AGEs have been implicated in a number of pathological processes associated not only with micro- and macrovascular disease complications in diabetes, but also in hypertension, cardiovascular disease and atherosclerosis. Low levels of sRAGE have been proposed as biomarkers for many diseases. Evidence acquisition process was performed using PubMed and Medline databases with manually checked articles. A total of 44 articles presenting current knowledge on AGEs, sRAGE and endogenous secretory RAGE (esRAGE), with special focus on their role in the pathogenesis of coronary disease, were reviewed to understand the pathophysiological mechanisms of these receptors. In this review, we discuss structure and function of AGE-RAGE axis in the context of hypertension and cardiovascular diseases.
\end{abstract}

Keywords: advanced glycation end products, cardiovascular diseases, hypertension, AGE receptor, soluble AGE receptor

Końcowe produkty zaawansowanej glikacji (advanced glycation end products, AGEs) i ich interakcje z receptorem dla zaawansowanych produktów glikacji (receptor for advanced glycation end products, RAGE) odgrywają ważną rolę w patogenezie wielu chorób. RAGE to białka powierzchniowe należące do rodziny immunoglobulin, które wiążą wiele rodzajów ligandów: S100/kalgranulinę, amfoterynę, włókna amyloidu, leukocytarną integrynę i transtyretynę. Należą do nich również AGEs. Na skutek związania receptora RAGE z AGEs dochodzi do uruchomienia wielu szlaków sygnałowych wewnątrz komórki: wzmożonej produkcji reaktywnych form tlenu, cytokin prozapalnych, cząsteczek adhezyjnych oraz aktywacji jądrowego czynnika transkrypcyjnego (NF-kB). Rozpuszczalna (soluble) izoforma receptora - sRAGE - stanowi „pułapkę" dla ligandów, przeciwdziałając negatywnym skutkom ich połączenia. Według aktualnych doniesień wzrost stężenia AGEs wiąże się z rozwojem powikłań w postaci nie tylko mikro- i makroangiopatii cukrzycowej, ale również nadciśnienia tętniczego, chorób układu sercowo-naczyniowego oraz miażdżycy. Najnowsze doniesienia sugerują, że obniżone stężenie sRAGE może służyć jako przydatny marker diagnostyczny. Dokonano analizy literatury na podstawie słów kluczowych oraz w odniesieniu do baz PubMed i Medline. W celu przybliżenia mechanizmu działania osi AGE-RAGE wyselekcjonowano czterdzieści cztery opracowania, ze szczególnym uwzględnieniem roli receptora RAGE w patogenezie nadciśnienia tętniczego oraz chorób układu sercowo-naczyniowego.

Słowa kluczowe: końcowe produkty zaawansowanej glikacji, choroby układu sercowo-naczyniowego, nadciśnienie tętnicze, receptor dla AGE, rozpuszczalna forma receptora dla AGE 


\section{INTRODUCTION}

$\mathrm{T}$ he pathway leading to advanced glycation end product (AGE) formation and accumulation is integrally associated with high blood glucose. The process of binding AGEs to receptor for advanced glycation end products (RAGE) gives rise to a wide range of deleterious effects. The developing oxidative stress leads to activation of intracellular pathways and release of proinflammatory cytokines, adhesive molecules, chemokines, matrix metalloproteinases and nitric oxide $(\mathrm{NO})$, which induce endothelial dysfunction and other detrimental vascular effects.

This review focuses on the characterisation of the AGEs-RAGE axis and its role in modern-world diseases, such as hypertension (HTN) and cardiovascular diseases (CVDs). Furthermore, we briefly described conditions where the levels of AGEs, sRAGE (soluble RAGE) and esRAGE (endogenous secretory RAGE) are decreased or elevated.

\section{CHARACTERISATION AND FUNCTION OF AGE-RAGE}

Glycosylation is an enzymatic process in which a carbohydrate is attached to a protein or other organic molecule. In contrast to glycosylation, which occurs under physiological conditions, glycation is a non-enzymatic reaction between proteins, nucleic acids, lipids and reducing sugars (glucose or fructose), leading to formation of AGEs ${ }^{(1)}$. Glycation, also known as the Maillard reaction, is a multistage process with many transformations. Initially, the free amino groups of amino acids (like lysine or arginine) react with the aldehyde group of reducing sugars to form the Schiff base, which is a very unstable product that undergoes rearrangements to form Amadori product. Then the complex may undergo many spontaneous reactions, such as oxidative or non-oxidative degradation, polymerisation and other rearrangements giving rise to a heterogeneous group of irreversible abducts described as AGEs ${ }^{(2)}$ (Fig. 1). AGE formation begins under hyperglycaemic, oxidative stress conditions or during ageing, and can be triggered by e.g. glucose-6-phosphate, glyceraldehyde3-phosphate, glyoxal, methylglyoxal and 3-deoxyglucosone. The products can be grouped into: cross-linking AGEs with fluorescence like pentosidine, non-cross-linking AGEs, such as $N^{\varepsilon}$-carboxy-methyl-lysine (CML), and nonfluorescent cross-linking AGEs like imidazolium dylisine cross-links ${ }^{(3)}$. In addition, there are many other different pathways that may lead to AGE formation even in the absence of glucose.

There are three types of receptors for AGEs: 1) A full length AGE receptor (RAGE) which is a multiligand cell-bound receptor; 2) N-truncated RAGE; 3) C-terminal RAGE having two isoforms, cleaved RAGE (cRAGE) and endogenous secretory RAGE (esRAGE). Whereas cRAGE is proteolytically cleaved from full length RAGE, esRAGE is formed as a result of alternative AGER mRNA splicing of full length RAGE $^{(4)}$. Total soluble RAGE (sRAGE) consists of cRAGE and esRAGE circulating in the blood. The esRAGE accounts for $30 \%$ of all sRAGEs ${ }^{(5)}$. AGEs induce pathology in a two-way manner: first, they alter the structural features of a protein by forming cross-links, then they interact with their receptors (RAGEs). Interaction with a full length RAGE activates inflammatory signalling pathways, such as nuclear factor (NF- $\mathrm{kB}$ ), and several mitogen-activated protein kinases (MAPKs), increases gene expression and release of inflammatory cytokines and increases generation of reactive oxygen species ${ }^{(6)}$. Both sRAGE and esRAGE act as a decoy for RAGE when binding with its ligand, hence their protective effects against AGE-RAGE interaction consequences ${ }^{(7)}$.

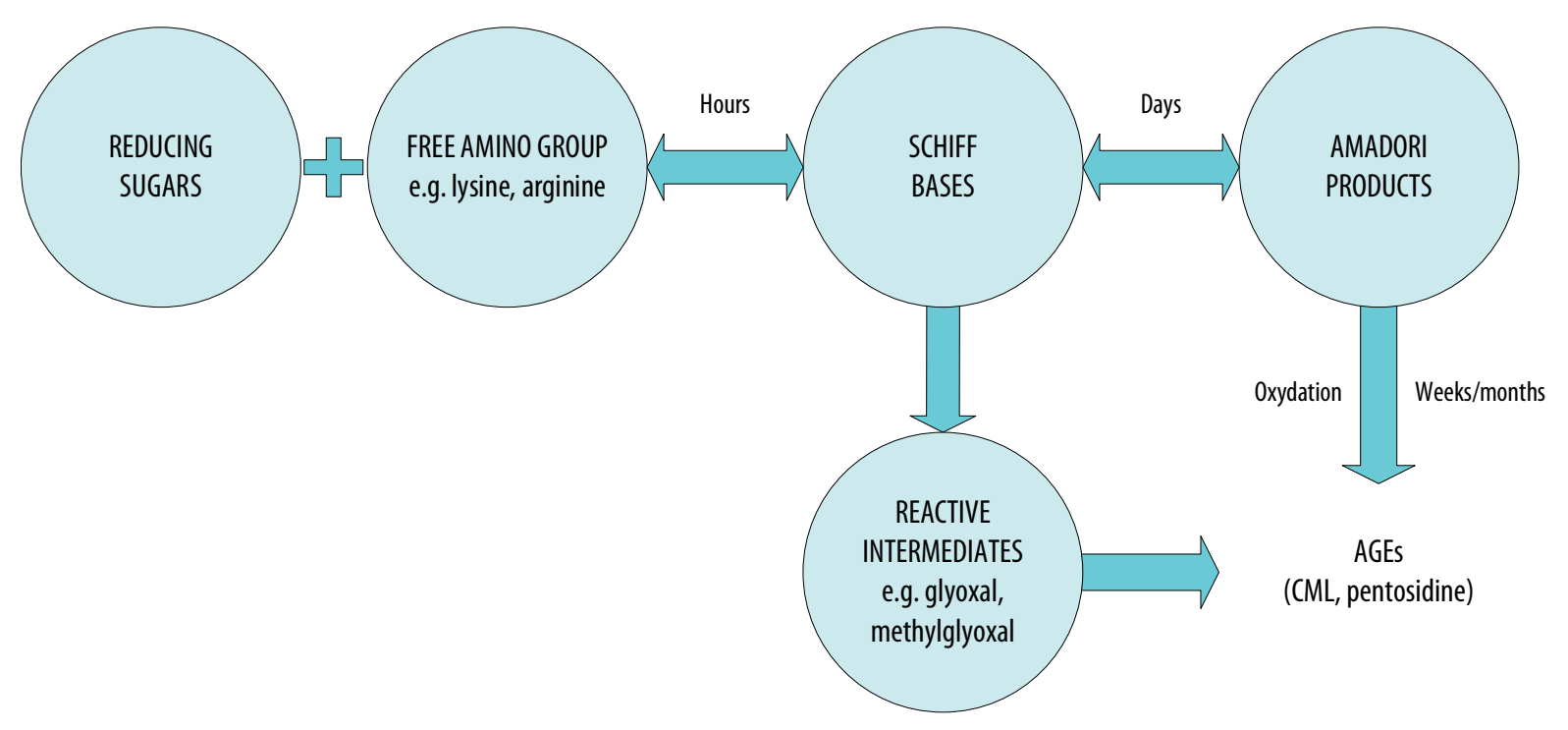




\section{A RELATIONSHIP BETWEEN AGE-RAGE AND DISEASES}

Low levels of sRAGE have been considered to be a marker of many diseases, but increased levels of sRAGE have been also reported in several conditions.

AGE levels are increased in the lungs of patients with chronic obstructive pulmonary disease (COPD), while reduced sRAGE levels are seen in clinically stable COPD and are correlated with more severe lung disease, regarding lung function or emphysema ${ }^{(8-11)}$. Serum levels of sRAGE are higher in type 1 and 2 diabetes compared with controls ${ }^{(12,13)}$. Turk et al. showed that esRAGE levels are decreased in diabetic patients with hyperlipidaemia. Furthermore, a high AGEs/esRAGE ratio is a significant independent factor contributing to diabetic macrovascular disease $\mathrm{e}^{(14)}$. Some clinical studies indicate that the AGE-RAGE interaction appears to play a major role in inflammation and retinal microvascular dysfunction in diabetic retinopathy. Moreover, increased formation of AGEs in the vitreous may be involved in the development of diabetic retinopathy by inducing the production of basic fibroblast growth factor (bFGF) by retinal Müller cells ${ }^{(15)}$. It has been shown that AGEs induce podocyte damage and detachment in diabetic nephropathy ${ }^{(16)}$. Also, AGEs induce transforming growth factor- $\beta$ expression in renal components such as podocytes, mesangial cells and proximal tubular cells, thereby contributing to glomerulosclerosis and tubulointerstitial fibrosis in diabetic nephropathy ${ }^{(17)}$. Elevated sRAGE serum levels are observed in patients with impaired renal function and end-stage renal disease ${ }^{(18)}$. Wang et al. reported that serum esRAGE levels in patients with heart failure are decreased in both diabetic and nondiabetic patients ${ }^{(19)}$. A recent study indicated that serum sRAGE correlates with decreased bone density, ranging from the level of osteopenia to marked osteoporosis, which supports the correlation between serum sRAGE and the bone density ${ }^{(20)}$. There are several diseases in which serum sRAGE levels are decreased: coronary artery disease and atherosclerosis ${ }^{(21,22)}$, hypercholesterolaemia ${ }^{(23)}$, Alzheimer disease and vascular dementia ${ }^{(24)}$.

\section{AGE-RAGE AND ESSENTIAL HTN}

There are two types of HTN. Essential, idiopathic, or primary HTN with unknown reason accounts for up to $95 \%$ of all HTN cases. Secondary HTN with known aetiology accounts for $5-10 \%$ of all HTN cases. It is well known that HTN is a risk factor for CVDs, including stroke, myocardial infarction and heart failure. There is a close relationship between arterial stiffness and blood pressure. At normal arterial pressures, the stiffness is due to elastin fibres, but at elevated blood pressure (systolic above $200 \mathrm{~mm} \mathrm{Hg}$ ), collagen fibres induce stiffness. Vascular stiffness can also be altered by vascular smooth muscle cell and endothelial signalling ${ }^{(25)}$. Studies suggest that the AGE-RAGE axis is involved in arterial stiffness in two ways: changes in arterial structure and vascular function. Structural changes leading to arterial stiffness comprise fragmentation of elastin, arterial calcification, increased amount of collagen, glycation of elastin and collagen, and cross-linking of collagen with AGEs ${ }^{(26)}$. AGEs build-up on extracellular matrix proteins leads to the formation of cross-links which alter collagen properties and make them insoluble to hydrolytic enzymes ${ }^{(27)}$. Cross-linking and glycation process increase the amount of collagen and decrease the amount of elastin in the arterial wall ${ }^{(28)}$. The elasticity of the arterial wall is further reduced by cross-linking of AGEs with elastin. Moreover, arterial stiffness may be intensified by nitric oxide reduction via the following mechanisms: matrix-bound AGEs inhibit antiproliferative activity of NO, impair prostacyclin and NO production, reduce the half-life of NO synthase and increase the expression of endothelin- $1^{(29,30)}$. There are several studies on AGEs, sRAGE and esRAGE levels in HTN. McNulty et al. have demonstrated that plasma AGE levels were significantly higher in untreated hypertensive patients compared to normotensive subjects (7.84 \pm 0.94 vs. $2.97 \pm 0.94 \mu \mathrm{g} / \mathrm{mL})$ and pointed to a positive correlation between plasma AGE levels and aortic pulse wave velocity (PWV) - an indicator of arterial stiffness in hypertensive patients ${ }^{(31)}$. Mayer et al. measured serum sRAGE levels in 1,077 patients ${ }^{(32)}$. They reported decreased sRAGE in nondiabetic hypertensive patients. They also showed that low levels of serum sRAGE were independently associated with elevated arterial stiffness (increased PWV) in nondiabetic hypertensive participants. In their study, Liu et al. showed that serum sRAGE was lower in patients with essential HTN with left ventricular hypertrophy ( $\mathrm{LVH}$ ) than those without $\mathrm{LVH}^{(33)}$. Dimitriadis et al. showed that decreased sRAGE levels accompany albuminuria and arterial stiffening in hypertensives. Moreover, the association of sRAGE with albumin to creatinine ratio and carotid-to-femoral pulse wave velocity (c-f PWV) implies sRAGE involvement in the progression of hypertensive vascular damage ${ }^{(34)}$. Huang et al., in their study in 1,051 Chinese participants, including 390 hypertensive patients, indicated that plasma AGEs were associated with stiffness in the carotid and femoral arteries assessed by PWV. Furthermore, the relationship between AGEs and PWV was stronger in patients with HTN and the levels of AGEs were significantly associated with central and peripheral augmentation index ${ }^{(35)}$.

In general, the data suggest that serum sRAGE and esRAGE levels are decreased in patients with HTN and arterial stiffness.

\section{AGE-RAGE AND CVD}

CVD is an outstanding cause of increased morbidity and mortality despite significant advances in prevention, diagnosis, and treatment of the disease over the years. CVD includes coronary artery diseases (CAD) such as angina and myocardial infarction. RAGE plays an important 
role in the development of CVD, and sRAGE may reflect RAGE activity, thus accentuates the role of sRAGE as a biomarker ${ }^{(36)}$. The clinical significance of sRAGE plasma levels in CAD has been investigated in various studies with equivocal results in different ethnicities and patients with comorbidities.

Both Cai et al. and Park et al. reported increased sRAGE in patients with acute coronary syndrome (ACS) compared to healthy controls ${ }^{(36,37)}$. Basta et al. showed that there was no difference in sRAGE levels in non-ST-segment elevation myocardial infarction (non-STEMI) patients compared to those with stable CAD ${ }^{(38)}$. Thus, sRAGE levels were higher in patients with elevated cardiac troponin I (TnI). Elevated sRAGE was related to in-hospital cardiac events. A prospective observational study conducted by Qiu et al. compared a group including STEMI patients with coronary artery disease and a control group of patients without $\mathrm{CAD}^{(39)}$. Each group comprised a different number of patients with or without diabetes. The levels of AGEs and sRAGE were assessed along with creatine kinase-myocardial band (CK-MB), cardiac TnI, and $\mathrm{N}$-terminal pro-brain natriuretic peptide (NT-proBNP) levels. STEMI patients showed elevated levels of AGEs and sRAGE as compared to controls. Moreover, diabetic patients in the STEMI group presented with higher levels of AGEs and sRAGE compared to nondiabetic patients. Furthermore, the level of AGEs correlated with the peak level of CK-MB in the general population of patients with STEMI and with the peak level of NT-proBNP in diabetics with STEMI. These markers could serve as indicators of the severity of cardiac injury and as predictors of prognosis. Park et al. evaluated the effects of diabetes on sRAGE levels and reported higher plasma sRAGE levels in patients with acute myocardial infarction (AMI) than in controls; however, regardless of the presence of diabetes ${ }^{(37)}$. On the contrary, McNair et al. found lower levels of sRAGE in patients with non-STEMI compared to controls ${ }^{(40,41)}$. Two different studies by Jensen et al. in STEMI patients treated with percutaneous coronary intervention (PCI) reported increased sRAGE levels with higher New York Heart Association (NYHA) classification. Elevated sRAGE levels were observed prior to and immediately after PCI followed by decreased levels on day 1 and day 2 after PCI. sRAGE was an independent predictor of cardiac dysfunction assessed by decreased left ventricular ejection fraction (LVEF) $)^{(42,43)}$. Reichert et al. enrolled 886 patients with angiographically proven CVD in their three-year longitudinal cohort study. They showed the highest incidence of recurrent CVD events in patients with sRAGE levels $>838.19 \mathrm{pg} / \mathrm{mL}(24.9 \%$ versus $13.1 \%, p<0.0001)$. Furthermore, the correlation between sRAGE and new CVD events was confirmed ${ }^{(44)}$.

To conclude, most of the available research pointed to elevated AGE and sRAGE levels. Furthermore, these factors could probably serve as biomarkers to indicate the severity of CVDs.

\section{CONCLUSION}

Taken together, AGEs, the product of nonenzymatic glycation, are known to accumulate in plasma and tissues over a period of time. Moreover, they can induce cell structure damage, directly or indirectly, due to oxidative stress, glycoxydation and lipooxydation. There is emerging evidence that they are involved in the pathogenesis of diabetes, CVD, HTN and other diseases. Moreover, AGE and sRAGE levels vary in particular diseases. They could serve as markers of the CVD development and progression due to their correlation with the disease severity, predicting the development of cardiovascular complications.

\section{Conflict of interest}

The authors declare that they have no conflict of interests and give their consent for publication. The authors alone are responsible for the content and writing of the paper.

\section{References}

1. Ahmad S, Khan MS, Akhter F et al.: Glycoxidation of biological macromolecules: a critical approach to halt the menace of glycation. Glycobiology 2014; 24: 979-990.

2. Ahmed N: Advanced glycation end products - role in pathology of diabetic complications. Diabetes Res Clin Pract 2005; 67: 3-21.

3. Thornalley PJ: Dicarbonyl intermediates in the Maillard reaction. Ann N Y Acad Sci 2005; 1043: 111-117.

4. Yonekura H, Yamamoto Y, Sakurai S et al.: Novel splice variants of the receptor for advanced glycation end-products expressed in human vascular endothelial cells and pericytes, and their putative roles in diabetes-induced vascular injury. Biochem J 2003; 370: 1097-1109.

5. Koyama H, Shoji T, Yokoyama $\mathrm{H}$ et al.: Plasma level of endogenous secretory RAGE is associated with components of the metabolic syndrome and atherosclerosis. Arterioscler Thromb Vasc Biol 2005; 25 : 2587-2593.

6. Schmidt AM, Yan SD, Yan SF et al.: The biology of the receptor for advanced glycation end products and its ligands. Biochim Biophys Acta 2000; 1498: 99-111.

7. Geroldi D, Falcone C, Emanuele E: Soluble receptor for advanced glycation end products: from disease marker to potential therapeutic target. Curr Med Chem 2006; 13: 1971-1978.

8. Coxson HO, Dirksen A, Edwards LD et al.; Evaluation of COPD Longitudinally to Identify Predictive Surrogate Endpoints (ECLIPSE) Investigators: The presence and progression of emphysema in COPD as determined by CT scanning and biomarker expression: a prospective analysis from the ECLIPSE study. Lancet Respir Med 2013; 1: 129-136.

9. Wu L, Ma L, Nicholson LF et al.: Advanced glycation end products and its receptor (RAGE) are increased in patients with COPD. Respir Med 2011; 105: 329-336.

10. Smith DJ, Yerkovich ST, Towers MA et al.: Reduced soluble receptor for advanced glycation end-products in COPD. Eur Respir J 2011; 37: 516-522.

11. Miniati M, Monti S, Basta G et al.: Soluble receptor for advanced glycation end products in COPD: relationship with emphysema and chronic cor pulmonale: a case-control study. Respir Res 2011; 12: 37.

12. Colhoun HM, Betteridge DJ, Durrington $P$ et al.: Total soluble and endogenous secretory receptor for advanced glycation end products as predictive biomarkers of coronary heart disease risk in patients with type 2 diabetes: an analysis from the CARDS trial. Diabetes 2011; 60: 2379-2385.

13. Challier $M$, Jacqueminet $S$, Benabdesselam $O$ et al.: Increased serum concentrations of soluble receptor for advanced glycation endproducts in patients with type 1 diabetes. Clin Chem 2005; 51: 1749-1750. 
14. Turk Z, Ljubić S, Boras J: Decreased level of endogenous secretory receptor for advanced glycation end-products in diabetes with concomitant hyperlipidemia. Physiol Res 2014; 63: 199-205.

15. Ai J, Liu Y, Sun JH: Advanced glycation end-products stimulate basic fibroblast growth factor expression in cultured Müller cells. Mol Med Rep 2013; 7: 16-20.

16. Fukami K, Yamagishi S, Kaifu K et al.: Telmisartan inhibits AGEinduced podocyte damage and detachment. Microvasc Res 2013; 88: 79-83.

17. Yamagishi S, Inagaki $Y$, Okamoto $T$ et al.: Advanced glycation end products inhibit de novo protein synthesis and induce TGF- $\beta$ overexpression in proximal tubular cells. Kidney Int 2003; 63: 464-473.

18. Kalousová $M$, Hodková $M$, Kazderová $M$ et al.: Soluble receptor for advanced glycation end products in patients with decreased renal function. Am J Kidney Dis 2006; 47: 406-411.

19. Wang LJ, Lu L, Zhang FR et al.: Increased serum high-mobility group box-1 and cleaved receptor for advanced glycation endproducts levels and decreased endogenous secretory receptor for advanced glycation endproducts levels in diabetic and non-diabetic patients with heart failure. Eur J Heart Fail 2011; 13: 440-449.

20. Galliera E, Marazzi MG, Gazzaruso C et al.: Evaluation of circulating sRAGE in osteoporosis according to BMI, adipokines and fracture risk: a pilot observational study. Immun Ageing 2017; 14: 13.

21. Falcone C, Emanuele E, D'Angelo A et al.: Plasma levels of soluble receptor for advanced glycation end products and coronary artery disease in nondiabetic men. Arterioscler Thromb Vasc Biol 2005; 25: 1032-1037.

22. Lindsey JB, de Lemos JA, Cipollone F et al.: Association between circulating soluble receptor for advanced glycation end products and atherosclerosis: observations from the Dallas Heart Study. Diabetes Care 2009; 32: 1218-1220.

23. Santilli F, Bucciarelli L, Noto D et al.: Decreased plasma soluble RAGE in patients with hypercholesterolemia: effects of statins. Free Radic Biol Med 2007; 43: 1255-1262.

24. Emanuele E, D’Angelo A, Tomaino C et al.: Circulating levels of soluble receptor for advanced glycation end products in Alzheimer disease and vascular dementia. Arch Neurol 2005; 62: 1734-1736.

25. Zieman SJ, Melenovsky V, Kass DA: Mechanisms, pathophysiology, and therapy of arterial stiffness. Arterioscler Thromb Vasc Biol 2005; 25: 932-943.

26. Laurent S, Boutouyrie P, Lacolley P: Structural and genetic bases of arterial stiffness. Hypertension 2005; 45: 1050-1055.

27. Schmidt AM, Hori O, Chen JX et at.: Advanced glycation endproducts interacting with their endothelial receptor induce expression of vascular cell adhesion molecule-1 (VCAM-1) in cultured human endothelial cells and in mice. A potential mechanism for the accelerated vasculopathy of diabetes. J Clin Invest 1995; 96: 1395-1403.

28. Reiser K, McCormick RJ, Rucker RB: Enzymatic and nonenzymatic cross-linking of collagen and elastin. FASEB J 1992; 6: 2439-2449.

29. Hogan M, Cerami A, Bucala R: Advanced glycosylation endproducts block the antiproliferative effect of nitric oxide. Role in the vascular and renal complications of diabetes mellitus. J Clin Invest 1992; 90: 1110-1115.
30. Xu B, Chibber R, Ruggiero D et al.: Impairment of vascular endothelial nitric oxide synthase activity by advanced glycation end products. FASEB J 2003; 17: 1289-1291.

31. McNulty M, Mahmud A, Feely J: Advanced glycation end-products and arterial stiffness in hypertension. Am J Hypertens 2007; 20: 242-247.

32. Mayer O, Seidlerová J, Filipovský J et al.: Soluble receptor for advanced glycation end products and increased aortic stiffness in a general population. Hypertens Res 2016; 39: 266-271.

33. Liu Q, Chen HB, Luo M et al.: Serum soluble RAGE level inversely correlates with left ventricular hypertrophy in essential hypertension patients. Genet Mol Res 2016; 15.

34. Dimitriadis K, Tsioufis C, Kasiakogias A et al.: Soluble receptor for advanced glycation end-product levels are related to albuminuria and arterial stiffness in essential hypertension. Nutr Metab Cardiovasc Dis 2013 ; 23 : $382-388$.

35. Huang QF, Sheng CS, Liu M et al.: Arterial stiffness and wave reflections in relation to plasma advanced glycation end products in a Chinese population. Am J Hypertens 2013; 26: 754-761.

36. Cai XY, Lu L, Wang YN et al.: Association of increased S100B, S100A6 and S100P in serum levels with acute coronary syndrome and also with the severity of myocardial infarction in cardiac tissue of rat models with ischemia-reperfusion injury. Atherosclerosis 2011; 217: 536-542.

37. Park HJ, Baek JY, Shin WS et al.: Soluble receptor of advanced glycated endproducts is associated with plaque vulnerability in patients with acute myocardial infarction. Circ J 2011; 75: 1685-1690.

38. Basta G, Del Turco S, Marchi F et al.: Elevated soluble receptor for advanced glycation end product levels in patients with acute coronary syndrome and positive cardiac troponin I. Coron Artery Dis 2011; 22: 590-594

39. Qiu H, Li WP, Shen XH et al.: Dynamic fluctuations of advanced glycation end products and its C-terminal truncated receptor level in patients with acute ST-segment elevation myocardial infarction and undergoing diabetes or not: a retrospective study. Medicine (Baltimore) 2018; 97: e11278.

40. McNair ED, Wells CR, Qureshi AM et al.: Inverse association between cardiac troponin-I and soluble receptor for advanced glycation end products in patients with non-ST-segment elevation myocardial infarction. Int J Angiol 2011; 20: 49-54.

41. McNair ED, Wells CR, Qureshi AM et al.: Low levels of soluble receptor for advanced glycation end products in non-ST elevation myocardial infarction patients. Int J Angiol 2009; 18: 187-192.

42. Jensen LJ, Munk K, Flyvbjerg A et al.: Soluble receptor of advanced glycation end-products in patients with acute myocardial infarction treated with remote ischaemic conditioning. Clin Lab 2015; 61: 323-328.

43. Jensen LJ, Lindberg S, Hoffmann S et al.: Dynamic changes in sRAGE levels and relationship with cardiac function in STEMI patients. Clin Biochem 2015; 48: 297-301.

44. Reichert S, Triebert U, Santos AN et al.: Soluble form of receptor for advanced glycation end products and incidence of new cardiovascular events among patients with cardiovascular disease. Atherosclerosis 2017; 266: 234-239. 